\title{
KARAKTERISTIK MUTU HEDONIK DAN PROKSIMAT NUGGET IKAN LELE DUMBO (Clarias gariepinus) MENGGUNAKAN TEPUNG BIJI DURIAN (Durio Zibethinus murr)
}

\author{
Fenski Mursali ${ }^{1}$, Nikmawatisusanti Yusuf*1 \\ 1 Jurusan Teknologi Hasil Perikanan, Fakultas Perikanan dan Ilmu Kelautan, Universitas Negeri Gorontalo, \\ Jl.Jenderal Sudirman No.06, Kota Gorontalo 96128, Gorontalo, Indonesia \\ *Korespondensi: nikmawatisusantiyusuf@gmail.com \\ (Diterima 28-01-2021; Direvisi 30-01-2021; Dipublikasi 31-01-2021)
}

\begin{abstract}
ABSTRAK
Penelitian ini bertujuan untuk menganalisis karakteristik organoleptik dan kimia nugget ikan lele dumbo (Clarias gariepinus) menggunakan tepung biji durian (Durio zibethinus murr). Perlakuan pada penelitian ini adalah penggunaan konsentrasi tepung biji durian yang berbeda yaitu $10 \mathrm{~g}, 20 \mathrm{~g}$ dan $30 \mathrm{~g}$. Parameter yang diuji adalah karakteristik organoleptik hedonik yang meliputi tekstur, kenampakan, warna, aroma dan rasa yang menggunakan uji Kruskal Wallis, parameter kimia meliputi kadar air, abu, lemak, protein dan karbohidrat yang menggunakan RAL (Rancangan Acak Lengkap). Hasil uji Kruskal Wallis menunjukan penambahan tepung biji durian tidak berpengaruh nyata terhadap kenampakan, warna, aroma, dan tekstur, tetapi berpengaruh nyata terhadap rasa. Hasil uji RAL (Rancangan Acak Lengkap) menunjukan penambahan tepung biji durian tidak berpengaruh nyata terhadap parameter kimia (kadar air, kadar protein, abu), tetapi berpengaruh nyata terhadap kadar lemak dan karbohidrat.
\end{abstract}

Kata Kunci: Lele Dumbo; Mutu Hedonik; Nugget; Proksimat; Tepung Biji Durian.

\section{Hedonic Quality Characteristics And Nugget Proximates \\ Dumbo Lele Fish (Clarias gariepinus) Using Flour Durian Seeds (Durio Zibethinus murr)}

\begin{abstract}
This study aims to analyze the organoleptic and chemical characteristics of African catfish nuggets (C. gariepinus) using durian seed flour (Durio zibethinus murr). The treatment in this study was the use of different concentrations of durian seed flour, namely $10 \mathrm{~g}, 20 \mathrm{~g}$ and $30 \mathrm{~g}$. The parameters tested were hedonic organoleptic characteristics which included texture, appearance, color, aroma and taste using the Kruskal Wallis test, chemical parameters including moisture, ash, fat, protein and carbohydrate content using CRD (Completely Randomized Design). The Kruskal Walllis test results showed that the addition of durian seed flour had no significant effect on appearance, color, aroma, and texture, but had a significant effect on taste. The results of the CRD test (completely randomized design) showed that the addition of durian seed flour had no significant effect on chemical parameters (moisture content, protein content, ash), but had a significant effect on fat and carbohydrate content.
\end{abstract}

Keywords: Dumbo Catfish; Hedonic Quality; Nugget; Proximate; Durian Seed Flour. 


\section{PENDAHULUAN}

Diversifikasi produk olahan hasil perikanan merupakan salah satu alternatif pemecahan masalah dalam menghindari kejenuhan pasar dan penyediaan gizi masyarakat, oleh karena itu perlu dikembangkan usaha pengolahan bahan pangan hasil perikanan yang menuju arah diversifikasi dan peningkatan mutu bahan pangan sebagai salah satu upaya untuk meningkatkan pemanfaatan dan konsumsi hasil perikanan di Gorontalo khususnya. Lele (Clarias sp) merupakan komoditas budidaya air tawar yang sangat digemari oleh masyarakat karena rasanya yang enak dan gurih. Bahkan saat ini lele tidak hanya dikonsumsi dalam bentuk utuhnya tapi juga sudah dalam bentuk olahan seperti bakso, kerupuk kulit, abon, nugget dan lain-lain. Pengolahan ikan lele yang kurang bervariasi cenderung kurang disukai oleh masyarakat, padahal lele memiliki kandungan gizi yang sangat baik (Sarjito, 2013).

Ikan lele yang banyak dibudidayakan oleh masyarakat Gorontalo adalah ikan lele dumbo. Ikan lele dumbo (Clarias gariepinus) merupakan komoditas ikan air tawar yang mempunyai nilai ekonomis tinggi dan bisa dipelihara pada padat penebaran tinggi, sehingga memicu para pembudidaya untuk membudidayakan ikan ini secara intensif dan super intensif. Keunggulan ikan lele dumbo, yaitu pertumbuhan yang cepat, tahan terhadap perubahan lingkungan dan bisa di budidayakan pada berbagai wadah (Iswanto, 2013).

Penggunaan ikan lele dalam penelitian ini karena bagi sebagian orang tidak ingin mengkonsumsi ikan lele dalam bentuk segar karena bentuknya yang menyerupai hewan melatah, mudah dibudidayakan, dan memiliki kandungan gizi yang tinggi yaitu protein $(17,7 \%)$ dan lemak $(14,8)$ yang dapat melengkapi kebutuhan gizi manusia (Tarigan, dkk., 2016). Masyarakat semakin menginginkan makanan yang praktis dan cepat saji. Nugget adalah salah satu produk makanan yang mudah dibuat, cara pengolahannya cepat dan tidak membutuhkan waktu yang lama. Hal ini adalah alasan yang melatarbelakangi penggunaan produk nugget dalam penelitian ini. Nugget adalah suatu bentuk produk olahan daging yang merupakan bentuk emulsi minyak dalam air. Faktor yang mempengaruhi keberhasilan produk ini yaitu pada kemampuan mengikat antara partikel daging dan bahan-bahan lain yang ditambahkan (Yenrina, dkk., 2012).

Biji durian (Durio zibethinus Murr) merupakan limbah pertanian yang cenderung meresahkan masyarakat disaat musim buah durian. Bagian buah durian yang lebih umum dikonsumsi adalah bagian salut buah atau dagingnya. Persentase berat bagian ini termasuk rendah yaitu hanya 20 $35 \%$. Hal ini berarti kulit $(60-75 \%)$ dan biji $(5-15 \%)$ belum termanfaatkan secara maksimal. Pemanfaatan limbah yang belum mempunyai nilai ekonomis, berlimpah dan mengandung gizi relatif baik dapat mengurangi pencemaran lingkungan adalah tindakan bijaksana. 
Menurut Rofaida (2008) pengubahan bentuk biji durian menjadi tepung akan mempermudah pemanfaatan biji durian menjadi bahan setengah jadi yang fleksibel, karena memiliki daya simpan yang lama dan digunakan sebagai penganekaragaman pengolahan bahan makanan. Pati biji durian memiliki kesamaan dengan tepung tapioka yaitu memiliki kadungan pati yang terdiri dari amilosa dan amilopektin, sehingga dapat digunakan sebagai bahan pengisi.

Penggunaan biji durian pada penelitian ini karena biji durian merupakan limbah yang kurang dimanfaatkan, memiliki kandungan pati yang tinggi sebagai bahan pengikat, memiliki kandungan gizi yang cukup tinggi, oleh karena itu peneliti mencoba untuk membuat produk nugget lele dumbo dengan menggunakan tepung biji durian. Tujuan dari penelitian ini adalah untuk menganalisis karakteristik organoleptik mutu hedonik dan kimiawi nugget ikan lele dumbo dengan menggunakan tepung biji durian.

\section{METODE PENELITIAN}

\section{Waktu dan Tempat}

Penelitian ini dilaksanakan pada bulan Juni hingga September. Pengujian kimia dilakukan di Balai Pembinaan dan Pengujian Mutu Hasil Perikanan (BPPMHP) Provinsi Gorontalo.

\section{Alat dan Bahan}

Alat yang digunakan dalam pembuatan tepung ikan adalah talenan, pisau, loyang, blender/alat penggiling, panci pengukusan, saringan, sendok, kompor, oven, termometer, dan timbangan. Alat yang digunakan pada pembuatan nugget yaitu loyang, timbangan, sendok, baskom, saringan, pisau, kompor, wajan, dan wadah pencetakan. Alat yang digunakan dalam proses pengujian adalah alat-alat gelas Pyrex, hot plate, desikator, tungku pengabuan, soxhlet, pipet, termometer.

Bahan baku yang digunakan dalam pembuatan kukis bagea adalah daging ikan lele dumbo (Clarias gariepinus) dan biji durian (Durio Zibethinus murr). Bahan tambahan yang digunakan yaitu tepung roti, garam beryodium, telur ayam, minyak goreng, lada, gula, bawang putih, bawang merah, wortel, dan air bersih. Bahan yang digunakan untuk dalam pengujian kimia adalah $\mathrm{K}_{2} \mathrm{SO}_{4}, \mathrm{H}_{2} \mathrm{SO}_{4}$, $\mathrm{HgO}, \mathrm{NaOH}, \mathrm{HNO}_{3}, \mathrm{HCl}, \mathrm{Na}_{2} \mathrm{~S}_{2} \mathrm{O}_{3}, \mathrm{H}_{2} \mathrm{BO}_{3}$, aquades, indikator (campuran metil merah dan metilen biru), petroleum eter, asam sulfat, natrium hidroksida, dan etanol.

\section{Prosedur penelitian}

\section{Proses pembuatan nuget}

Tepung biji durian yang sudah halus selanjutnya di olah menjadi nugget ikan dengan menentukan formulasi yang digunakan. Formulasi pada penelitian ini terdiri atas 3 perlakuan yaitu 
konsentrasi tepung biji durian $10 \mathrm{~g}, 20 \mathrm{~g}$, dan $30 \mathrm{~g}$ dengan jumlah ikan yang sama yaitu $100 \mathrm{~g}$ dan bumbu. Pembuatan nugget ikan lele dumbo yang diawali dengan penggilingan daging ikan sambil menambahkan air es sebanyak $5 \mathrm{ml}$. Tambahkan tepung biji durian, bawang puth, bawang merah, lada, garam, dan gula. Tepung biji durian ditambahkan sedikit demi sedikit (sesuai perlakuan) dan air hingga didapat adonan yang kalis. Adonan diletakan dalam wadah pencetakan, kemudian dilakukan pengukusan dengan suhu $\pm 80^{\circ} \mathrm{C}-100{ }^{\circ} \mathrm{C}$ selama 30 menit. Adonan yang telah matang didinginkan selama 10-15 menit. Selanjutnya dilakukan pemotongan dengan ukuran $\pm 1 \mathrm{~cm}$. Kemudian proses pemaniran dengan pencelupan ke dalam kocokan telur dan pelapisan dengan tepung roti, selanjutnya nugget digoreng dengan suhu suhu $1500^{\circ} \mathrm{C}-170{ }^{\circ} \mathrm{C}$ selama $2-3$ menit kemudian ditiriskan.

\section{Uji mutu hedonik}

Uji organoleptik yang dilakukan yaitu metode hedonik (uji tingkat kesukaan) menggunakan Scor sheet SNI (2006). Produk nuget dengan formulasi berbeda diuji hedonik untuk mengetahui tingkat kesukaan dari hasil formulasi tersebut. Data berupa hasil penilaian panelis yang diperoleh dari uji organoleptik hedonik dianalisis dengan menggunakan statistik non parametrik dengan metode uji Kruskal-Wallis (Walpole, 1993).

\section{Analisis proksimat}

Analisis proksimat mengacu pada BSN (2006) yaitu analisis kadar air, protein, lemak, abu, dan kadar karbohidrat berdasarkan perhitungan by difference. Data yang diperoleh pada masingmasing variabel pengujian dilakukan analisis ragam (ANOVA) dan uji lanjut Duncan jika terdapat pengaruh yang signifikan pada $a=0,05$ (skala kepercayaan 95\%) (Steel dan Torrie 1995).

\section{HASIL DAN PEMBAHASAN}

\section{Nilai Mutu Hedonik Nugget Ikan Lele Dumbo}

\section{Kenampakan}

Hasil uji organoleptik mutu hedonik menunjukan bahwa kenampakan dari ketiga formulasi berkisar antara 6,80 sampai 6,88, dan mendekati skala 7 , hal ini menunjukan bahwa rata-rata kenampakan dari tiap perlakuan memiliki karakteristik utuh, rapi, kurang bersih, dan kurang homogen. Berdasarkan hasil uji Krusskal wallis menunjukan bahwa penggunaan tepung biji durian yang berbeda tidak berpengaruh nyata terhadap kenampakan nugget ikan lele dumbo, hal ini sesuai dengan pernyataan Winarno (2008) bahwa kenampakan produk akhir salah satunya dipengaruhi oleh minyak goreng yang berfungsi sebagai medium penghantar panas, menambahkan rasa gurih, 
menambahkan nilai gizi dan cita rasa nugget, serta menambahkan kalori dalam nugget sehingga dari ketiga perlakuan dihasilkan kenampakan yang sama yaitu kuning kemerahan. Selain perubahan saat proses penggorengan, bahan pelapisan yang digunakan akan menghasilkan produk nugget yang seragam pada kenampakan produk akhir.

\section{Warna}

Hasil uji organoleptik mutu hedonik menunjukan bahwa warna dari ketiga formulasi berkisar antara 7,12 sampai 7,24, hal ini menunjukan bahwa rata-rata warna dari tiap perlakuan memiliki karakteristik warna kuning kemerahan. Berdasarkan hasil uji Krusskall wallis menunjukan bahwa penggunaan tepung biji durian tidak berpengaruh ternyata terhadap warna nugget ikan lele dumbo, hal ini sesuai dengan pernyataan Wellyalina, dkk. (2013), bahwa penggorengan bahan pangan dalam minyak goreng akan menyebabkan seluruh permukaan pangan menerima panas yang sama sehingga menghasilkan warna dan penampakan yang seragam. Penggorengan memicu terjadinya reaksi Mailard yang menghasilkan warna coklat yang diinginkan.

\section{Aroma}

Hasil uji organoleptik mutu hedonik menunjukan bahwa aroma dari ketiga formulasi berkisar antara 6,92 sampai 7,04, hal ini menunjukan bahwa rata-rata aroma dari tiap perlakuan memiliki karakteristik aroma ikan, bumbu, dan tepung biji durian kurang kuat. Berdasarkan uji Kruskal-Wallis menunjukan bahwa penambahan konsentrasi tepung biji durian yang berbeda tidak berpengaruh nyata terhadap aroma nugget ikan lele dumbo. Aroma nugget ikan diduga dipengaruhi oleh kandungan protein yang terurai menjadi asam-asam amino khususnya asam glutamat yang ada pada daging ikan dan bumbu. Menurut Erawaty (2001), aroma dari bumbu-bumbu seperti bawang putih, bawang merah dan lada dapat berfungsi sebagai penambah aroma pada produk nugget ikan yang dihasilkan.

\section{Tekstur}

Hasil uji organoleptik mutu hedonik menunjukan bahwa tekstur dari ketiga formulasi berkisar antara 6,96 sampai 7,20 , hal ini menunjukan bahwa rata-rata tekstur dari tiap perlakuan memiliki karakteristik tekstur yang kenyal, kompak, dan tidak padat. Berdasarkan uji Kruskal-Wallis, menunjukan bahwa penambahan konsentrasi tepung biji durian yang berbeda tidak berpengaruh nyata terhadap tekstur nugget ikan lele. Hal ini diduga karena penggunaan tepung biji durian dengan konsentrasi yang tidak jauh berbeda dan jumlah ikan yang digunakan sama, sehingga membentuk tekstur yang sama, hal ini sesuai dengan pernyataan Rospiati (2007) bahwa tekstur nugget akan 
berubah juga dipengaruhi oleh kandungan air. nugget merupakan produk yang memiliki karakteristik juicenes atau kesan kebasahan dibagian dalamnya.

\section{Rasa}

Hasil uji organoleptik mutu hedonik menunjukan bahwa rasa dari ketiga formulasi berkisar antara 6,64 sampai 7,28, hal ini menunjukan bahwa rasa dari perlakuan A dan B memiliki karakteristik rasa ikan, bumbu, dan tepung biji durian kurang kuat sedangkan perlakuan $\mathrm{C}$ memiliki karakteristik agak terasa ikan, bumbu, dan tepung biji durian sedikit. Berdasarkan hasil uji KruskalWallis, menunjukan bahwa penambahan konsentrasi tepung biji durian yang berbeda berpengaruh nyata pada rasa nugget ikan lele dumbo, hal ini diduga karena penggunaan tepung biji durian yang tidak sama, sehingga menghasilkan nilai yang berbeda. Menurut Ketaren (1986) dalam Mustar (2013) bahwa rasa diperoleh karena selama proses penggorengan, sebagian minyak masuk ke dalam bahan pangan dan mengisi ruang kosong yang pada mulanya diisi oleh air. Minyak mengandung lemak yang tinggi sehingga akan menambah cita rasa gurih.

\section{Kandungan Proksimat Nugget Ikan Lele Dumbo}

Kandungan proksimat pada nugget ikan lele meliputi kadar air, kadar abu, kadar lemak, kadar protein dan kadar karbohidrat dapat dilihat pada Tabel 1.

Tabel 1. Hasil Uji Proksimat Nugget Lele Dumbo

\begin{tabular}{llll}
\hline \multirow{2}{*}{ Parameter } & \multicolumn{3}{c}{ Sampel } \\
\cline { 2 - 4 } & \multicolumn{1}{c}{$\mathrm{A}$} & \multicolumn{1}{c}{$\mathrm{B}$} & \multicolumn{1}{c}{$\mathrm{C}$} \\
\hline Kadar Air & $29,04^{\mathrm{a}}$ & $28,35^{\mathrm{a}}$ & $27,97^{\mathrm{a}}$ \\
Kadar Abu & $1,11^{\mathrm{a}}$ & $1,23^{\mathrm{a}}$ & $1,30^{\mathrm{a}}$ \\
K.Lemak & $11,15^{\mathrm{a}}$ & $12,54^{\mathrm{b}}$ & $12,88^{\mathrm{b}}$ \\
K.Protein & $18,77^{\mathrm{a}}$ & $18,93^{\mathrm{a}}$ & $19,51^{\mathrm{a}}$ \\
K.Karbohidrat & $39,93^{\mathrm{a}}$ & $38,95^{\mathrm{b}}$ & $38,34^{\mathrm{b}}$ \\
\hline Ket: nilai yng dikuti denga huruf berbeda $(\mathrm{a}, \mathrm{b})$ menunjukkan berbeda nyata $(\mathrm{p}<0,05)$
\end{tabular}

Berdasarkan analisis ANOVA (tabel 1), penggunaan tepung biji durian pada pembuatan nugget ikan lele dumbo tidak berpengaruh nyata terhadap kadar air, diduga karena penggunaan jumlah ikan yang sama sehingga tidak terdapat perbedaan yang signifikan.

Menurut Nasiri, dkk (2010) dalam Yusuf (2011), kadar air merupakan faktor penting dalam menentukan minyak selama penggorengan. Penguapan menciptakan rongga selama penggorengan. Rongga kapiler tersebut bekerja sebagai jalur dalam makanan dan kemudian diisi oleh minyak. Ada hubungan yang berlawanan antara kehilangan kelembaban dan serapan minyak, kandungan minyak jadi lebih tinggi sehubungan dengan kadar air rendah. 
Berdasarkan analisis ANOVA (tabel 1.), penggunaan tepung biji durian pada pembuatan nugget ikan lele dumbo tidak berpengaruh nyata terhadap kadar abu, diduga karena pengunaan garam dan bumbu-bumbu yang digunakan, dimana masing-masing bahan memiliki komponen mineral yang berbeda-beda dan akan berpengaruh terhadap kadar abu nugget. Tinggi dan rendahnya nilai kadar abu pada produk yang digoreng tergantung dari lama dan suhu penggorengan (Mahmud, dkk. 2008).

Berdasarkan analisis ANOVA (tabel 1), penggunaan tepung biji durian pada pembuatan nugget ikan lele dumbo berpengaruh nyata terhadap kadar lemak, semakin meningkatnya konsentrasi penggunaan tepung biji durian, diikuti oleh peningkatan lemak di duga karena sifat tepung biji durian yang mampu mengikat air dan lemak, hal ini sesuai dengan pernyataan Sundari, dkk. (2015), bahwa kenaikan kadar lemak pada bahan pangan yang digoreng disebabkan karena adanya minyak goreng yang terserap oleh bahan pangan tersebut yang mengakibatkan kadar lemak bertambah pada saat proses penggorengan.

Berdasarkan analisis ANOVA (tabel 1), penggunaan tepung biji durian pada pembuatan nugget ikan lele dumbo tidak berpengaruh nyata terhadap kadar protein, hal ini diduga karena pada saat proses penggorengan sebagian minyak goreng akan menempati rongga-rongga bahan pangan menggantikan posisi air yang menguap sehingga konsentrasi protein menjadi lebih kecil akibat penggunaan suhu relatif tinggi (Sundari, $d k k$., 2015).

Berdasarkan analisis ANOVA (tabel 1), penggunaan tepung biji durian pada pembuatan nugget ikan lele dumbo berpengaruh nyata terhadap kadar karbohidrat, hal ini diduga karena karbohidrat dalam nugget berbentuk pati yang terdapat pada tepung biji durian. Pada tahap pencampuran daging ikan dengan tepung, air dalam daging ikan ikut terserap, selanjutnya pada proses penggorengan terjadi penguapan air karena adanya perpindahan panas, secara bersamaan terjadi proses gelatinisasi dan pengembangan, dimana tepung akan mengembang saat pemanasan, butir-butir pati yang ada akan mengembang dan berongga (Yusuf, 2011).

\section{SIMPULAN}

Hasil uji Kruskal Walllis menunjukan penambahan tepung biji durian tidak berpengaruh nyata terhadap kenampakan, warna, aroma, dan tekstur, tetapi berpengaruh nyata terhadap rasa. Hasil uji RAL (Rancangan Acak Lengkap) menunjukan penambahan tepung biji durian tidak berpengaruh nyata terhadap parameter kimia (kadar air, kadar protein, abu), tetapi berpengaruh nyata terhadap kadar lemak dan karbohidrat. 


\section{DAFTAR PUSTAKA}

Erawaty WR. 2001. Pengaruh Bahan Pengikat, Waktu Penggorengan, Dan Daya Simpan Terhadap Sifat Fisik Dan Organoleptik Prodak Nugget Ikan Sapu- Sapu (Hyposascus pardalis). [Skripsi]. Institut Pertanian Bogor.

Iswanto B. 2013. Ikan Lele Dumbo (Clarias gariepinus). Jurnal Media Akuakultur. 8(2):10-18

Mahmud MK, Hermana NA, Zulfianto RR, Apriyantono, Ngadiarti BH, Bernadus, Tinexcelli. 2008. Tabel Komposisi Pangan Indonesia (TKPI). PT. Gramedia Pustaka Utama. Jakarta.

Mustar. 2013. Studi Pembuatan Abon Ikan Gabus (Ophiocephalus striatus) Sebagai Makanan Suplemen (Food Suplement), [Skripsi]. Jurusan Teknologi Pertanian, Fakultas Pertanian Universitas Hasanuddin. Makassar.

Rofaida LL. 2008. Komparasi Uji Karbohidrat Pada Produk Olahan Makanan dari Tepung Terigu dan Tepung Biji Durian (Durio zibethinus Murr). [Skripsi]. Pendidikan Biologi Fakultas Keguruan dan Ilmu Pendidikan. Universitas Muhammadiyah. Surakarta.

Rospiati E. 2007. Evaluasi Mutu dan Nilai Gizi Nugget Daging Merah Ikan Tuna (Thunnus sp.) Yang Diberi perlakuan Titanium Dioksida. Tesis. Program Studi IImu Pangan. Institut Pertanian Bogor.

Sarjito, Siwi H, Sri H. 2013. Performa Pofil Darah Lele Dumbo (Clarias gariepinus) yang Terserang Penyakit Kuning Setelah Pemeliharaan Dengan Penambahan Vit. C Pada Pangan. Jurnal Perikanan dan Kelautan. 2(1): 113-125.

Sundari D, Almasyhuri, Lamid S. 2015. Pengaruh Proses Pemasakan Terhadap Komposisi Zat Gizi Bahan Pangan Sumber Protein. Jurnal Media Litbankes. 25(4: 235-247.

Tarigan AFJ, Evawany Y, Aritonang, Etti, 2016. Daya Terima Nugget Ikan Lele Memanfaatkan Tepung Kacang Merah dan Kandungan Gizinya. Fakultas Kesehatan. Universitas Medan.

Wellyalina, Azima F, Aisman. 2013. Pengaruh Perbandingan Tetelan Merah Tuna dan Tepung Maizena Terhadap Mutu Nugget. Jurnal aplikasi teknologi Pangan. 2 (1): 9-17.

Winarno FG. 2008. Kimia Pangan dan Gizi. Gramedia Pustaka Utama. Jakarta.

Yenrina R, Sayuti K, Putra YH. 2012. Peningkatan Kadar Kalsium Nugget Melalui Penambahan Tulang Ikan Tuna Pada Nugget Ikan Tuna. Widyakarya Nasional Pangan Dan Gizi X Presentasi dan Poster : 1811-1821.

Yusuf, N. 2011. Karakteristik Gizi dan Pendugaan Umur Simpan Savory Chips Ikan Nike (Awaous melanocephaus) [Tesis]. Pascasarjana Institut Pertanian Bogor. Bogor. 